\title{
OPTIMASI WAKTU EKSTRAKSI DAN RASIO BAHAN PER PELARUT EKSTRAK DAUN PEPAYA UNTUK UJI AKTIVITAS ANTIBAKTERI
}

\section{The Optimization of Extraction Time and Material Ratios per Solvent of Papaya Leaf Extract for Antibacterial Activity Test}

\author{
Anniversary Sabathani*, Simon Bambang Widjanarko, Sudarminto Setyo Yuwono \\ Jurusan Teknologi Hasil Pertanian - Fakultas Teknologi Pertanian - Universitas Brawijaya \\ Jalan Veteran - Malang 65145 \\ *Penulis Korespondensi: email sabathani2018@gmail.com
}

Disubmit: 14 Februari 2018 Direvisi: 2 Juli 2018 Diterima: 23 Desember 2018

\begin{abstract}
ABSTRAK
Tujuan penelitian ini adalah mengetahui kombinasi waktu sonikasi dan bahan per pelarut (b/v) ekstrak daun pepaya segar, yang menghasilkan respon total fenol, aktivitas antioksidan $\left(\mathrm{IC}_{50}\right)$, dan rendemen yang optimum; juga untuk mengetahui efek dari dosis ekstrak daun pepaya pada aktivitas antibakteri Escherichia coli dan Staphylococcus aureus. Ekstrak daun pepaya dihasilkan menggunakan metode ultrasonik dengan pelarut aquades. Rancangan penelitian menggunakan Response Surface Method, sedangkan desain eksperimen menggunakan General Factor Design, dengan satu faktor yang terdiri dari 6 tingkat dosis ekstrak daun pepaya, kontrol positif dan negatif, diulang 3 kali. Kontrol positif adalah kertas cakram mengandung $10 \mu \mathrm{g}$ ampisilin untuk bakteri Staphylococcus aureus, kertas-cakram mengandung $30 \mu \mathrm{g}$ kloramfenikol untuk Escherichia coli, sedangkan kontrol negatif adalah aquades steril. Hasil penelitian menunjukkan kombinasi b/v $16.92 \mathrm{~g} / 100 \mathrm{ml}$ dengan lama waktu ekstraksi daun pepaya 14.36 menit dan menghasilkan tiga respon optimum rendemen $2.89 \%$, total fenol $50.03 \mathrm{mgGAE} / \mathrm{g}$, dan aktivitas antioksidan $\left(\mathrm{IC}_{50}\right)$ 211.924 ppm. Ekstrak daun pepaya pada konsentrasi $3.125 \mathrm{mg} / \mathrm{ml}, 6.25 \mathrm{mg} / \mathrm{ml}$, dan $12.5 \mathrm{mg} / \mathrm{ml}$ tidak berpengaruh terhadap perkembangan bakteri Staphylococcus aureus dan Escherichia coli, dan berpengaruh mulai $25 \mathrm{mg} / \mathrm{ml}, 50 \mathrm{mg} / \mathrm{ml}, 100 \mathrm{mg} / \mathrm{ml}$. Hal ini menunjukkan bahwa ekstrak daun pepaya berpotensi menahan perkembangan bakteri Staphylococcus aureus dan Escherichia coli
\end{abstract}

Kata kunci: Optimasi; Daun Pepaya; Ekstrak; Uji Aktivitas Antibakteri

\begin{abstract}
The aim of this research is to determine the combination of time duration of sonication and the ratio of the weight of material per solvent of fresh papaya leaf, which can produce optimum response of total phenol, antioxidant activity $\left(\mathrm{IC}_{50}\right)$, and rendemen; and to figure out the effect of dose of papaya leaf extract on antibacterial activity, both Escherichia coli and Staphylococcus aureus. The papaya leaf extract is resulted by using ultrasonic method with water solvent. The experiment is designed by using response surface method and general factor design, with one factor consist of 6 levels of papaya leaf extract dose, negative, and positive control and is repeated 3 times. The positive control is disc-paper containing $10 \mu g$ ampicillin for Staphylococcus aureus, disc-paper containing $30 \mu \mathrm{g}$ chloramphenicol for Escherichia coli. The negative control is sterile aquadest. The results of the study shows a combination of the ratio the weight material per solvent $16.92 \mathrm{~g} / 100 \mathrm{ml}$ with the duration of papaya leaf extraction 14.36 minutes and yields three optimum responses: rendemen of $2.89 \%$, total phenol of $50.03 \mathrm{mgGAE} / \mathrm{g}$, and antioxidant activity (IC $\left.{ }_{50}\right) 211.924$ ppm, furthermore papaya leaf extract at concentrations of $3.125 \mathrm{mg} / \mathrm{ml}, 6.25 \mathrm{mg} / \mathrm{ml}$, and $12.5 \mathrm{mg} / \mathrm{ml}$ does not have any effect on the development of Staphylococcus aureus and Escherichia coli bacteria, and only has an effect of $25 \mathrm{mg} / \mathrm{ml}, 50 \mathrm{mg} / \mathrm{ml}, 100 \mathrm{mg} / \mathrm{ml}$. This suggests that papaya leaf extract has the potential to withstand the development of Staphylococcus aureus and Escherichia coli bacteria
\end{abstract}

Keywords: Antibacterial Activity Test; Extract; Optimation; Papaya Leaves 


\section{PENDAHULUAN}

Salah satu tanaman yang berfungsi sebagai tumbuhan obat yaitu daun pepaya yang telah didistribusikan ke negara tropis secara keseluruhan dan dikenal sebagai neutraceutical. Kasus infeksi merupakan penyakit yang banyak dijumpai pada kehidupan sehari-hari yang disebabkan oleh bakteri atau mikroorganisme yang patogen, yang dapat masuk ke dalam jaringan tubuh dan berkembang biak di dalam jaringan (Waluyo, 2004). Bakteri yang dapat menyebabkan infeksi tersebut adalah Staphylococcus aureus dan Escherichia coli (Brooks et al., 2013). Daun pepaya diketahui dapat bertindak sebagai antioksidan (Ayoola et al., 2008), antibakteri (Suresh et al., 2008), antikanker (Rahmat et al., 2002), dan antiinflamasi (Gamulle et al., 2012). Selain itu, daun pepaya memiliki kandungan kimia, yaitu alkaloid, saponin, dan flavonoid pada daun, akar dan kulit batangnya, mengandung polifenol pada daun dan akarnya, serta mengandung saponin pada bijinya (Astuti, 2009).

Polifenol, diketahui rentan degradasi oksidatif, terutama selama paparan dalam jangka panjang panas, cahaya, dan oksigen sehingga kondisi ekstraksi secara signifikan dapat mempengaruhi efisiensi ekstraksi, stabilitas dan hasil polifenol (Seigler et al., 2002). Metode ekstraksi dan konsentrasi pelarut serta jenis pelarut adalah faktor yang mempengaruhi hasil ekstraksi (Gaedcke et al., 2003). Metode ultrasonik telah diketahui lebih aman, lebih singkat, dan meningkatkan jumlah rendemen kasar serta dapat menurunkan suhu operasi pada ekstrak yang tidak tahan panas, sehingga cocok untuk diterapkan pada ekstraksi senyawa bioaktif tidak tahan panas (Zou et al., 2014). Pelarut aquades merupakan pelarut yang memiliki senyawa yang paling polar dibandingkan pelarut lainnya serta tidak beracun sehingga sangat baik untuk proses ekstraksi (Umam et al., 2012).

Optimasi digunakan sebagai alternatif terbaik dari suatu percobaan dan metode respon permukaan telah efektif dalam optimalisasi dan pemantauan proses makanan (Wangtueai dan Noomhorm, 2009). Metode respon permukaan adalah kumpulan teknik matematika dan stastistik yang berhubungan dengan perlakuan produk sampai output dengan menetapkan persamaan regresi untuk menggambarkan hubungan antara parameter input dan sifat produk (Cho et al.,
2004). Namun penelitian sebelumnya belum didukung dengan optimasi kandungan senyawa kimia yang terdapat pada ekstrak daun pepaya dengan metode ultrasonik, sehingga peneliti ingin mengetahui rendemen, total fenol, antivitas antioksidan dan antibakteri yang lebih optimal dalam potensi pemanfaatan oleh praktisi herbal dan untuk penggunaan komersial ke depan.

\section{METODE}

Bahan utama yang digunakan pada penelitian ini adalah daun pepaya (Carica papaya L.) segar yang didapat dari kebun pepaya petani Kelurahan Tlogomas Lowokwaru Malang. Karakteristik daun yang digunakan adalah lebar $\pm 11 \mathrm{~cm}$, berwarna hijau agak tua, berada pada ranting urutan 3-5 dari pucuk dan diambil pada pukul 05.0006.00 WIB. Daun papaya segar dibersihkan dari kotoran, selanjutnya diblender agar terpotong-potong menjadi kecil sebelum dilakukan proses ekstraksi. Pelarut yang digunakan untuk ekstraksi daun pepaya adalah aquades. Bahan-bahan kimia untuk analisis antara lain $\mathrm{HCl} 2 \mathrm{~N}, \mathrm{FeCl}_{3}, \mathrm{DPPH}$, asam galat, reagen Folin Ciocalteau, $\mathrm{H}_{2} \mathrm{SO}_{4}, \mathrm{NaOH}$, dan media untuk pengujian mikrobiologis serta etanol yang didapatkan dari toko bahan kimia di Malang dan Laboratorium di lingkungan Universitas Brawijaya.

Bahan-bahan yang digunakan untuk uji cakram adalah kertas cakram (paper disc) yang masing-masing berdiameter $6 \mathrm{~mm}$, cotton swap, biakan murni bakteri Escherichia coli dan Staphylococcus aureus, media TSA (tripton soy agar) untuk menumbuhkan Escherichia coli, dan media TCBSA (thiosulfat citrate bile salt agar) untuk menumbuhkan Staphylococcus aureus. Bahan bahan tersebut diperoleh dari Laboratorium Mikrobiologi Fakultas Kedokteran Universitas Brawijaya Malang. Alat-alat yang digunakan dalam pembuatan ekstrak daun pepaya meliputi timbangan (miyako), blender kering (Panasonic), dan beaker glass (Pyrex). Alat-alat yang digunakan dalam ekstraksi daun pepaya meliputi neraca analitik (Denver Instrument M-310), alat ekstraksi ultrasonik (horn), vacuum rotary evaporator (Buchi B-490), dan freezer (Gea AB-396-T-X). Selanjutnya alat yang digunakan dalam analisis ekstrak antioksidan meliputi glassware (Pyrex), desikator, oven 
listrik (Memmert U.30), spektrofotometer dan kuvet (Unico UV-2100), dan Vortex mixer (LW Scientific). Alat-alat yang digunakan uji total fenol adalah evaporator vakum, spektrofotometer UV-VIS. Adapun alat-alat yang digunakan untuk uji cakram adalah autoklaf untuk sterilisasi alat, micro pipet, dan inkubator.

Penelitian ini dibagi menjadi dua tahap yaitu tahap pertama adalah penelitian yang bertujuan untuk mengetahui kombinasi optimum dua faktor (variabel bebas) yaitu lama waktu ekstraksi $\left(\mathrm{x}_{1}\right)$ dan rasio berat bahan per volume pelarut $\left(x_{2}\right)$ ekstrak daun carica pepaya segar yang dapat menghasilkan rendemen $\left(\mathrm{y}_{1}\right)$, total fenol $\left(\mathrm{y}_{2}\right)$, dan aktivitas antioksidan $\left(\mathrm{y}_{3}\right)$ terbaik. Tujuan penelitian tahap kedua untuk mengetahui efek dari dosis ekstrak daun pepaya segar pada aktivitas antibakteri baik Escherichia coli dan Staphylococcus aureus. Rancangan penelitian tahap pertama menggunakan Respon Surface Method (RSM), sedangkan rancangan penelitian tahap kedua menggunakan General Factor Design, dengan satu faktor yang terdiri dari 6 tingkat dosis ekstrak daun pepaya, kontrol positif dan negatif, dan diulang sebanyak 3 kali. Dosis ekstrak daun pepaya level satu $=3.125 \mathrm{mg} / \mathrm{ml}$; level dua $=6.25 \mathrm{mg} / \mathrm{ml}$; level tiga $=12.5 \mathrm{mg} / \mathrm{ml}$; level empat $=25 \mathrm{mg} /$ $\mathrm{ml}$; level lima $=50 \mathrm{mg} / \mathrm{ml}$; level enam $=100$ $\mathrm{mg} / \mathrm{ml}$. Kontrol positif adalah kertas-cakram yang mengandung $10 \mu \mathrm{g}$ ampisilin untuk bakteri Staphylococcus aureus, kertas cakram yang mengandung $30 \mu \mathrm{g}$ kloramfenikol untuk Escherichia coli, sedangkan kontrol negatif adalah aquades steril.

\section{HASIL DAN PEMBAHASAN}

\section{Rendemen, Total Fenol, Aktivitas Antioksidan Ekstrak Daun Pepaya}

Hasil pengukuran rendemen, total fenol, aktivitas antioksidan ekstrak daun pepaya disajikan dalam Tabel 1 .

\section{Rendemen Ekstrak Daun Pepaya}

Pada Tabel 1 diketahui bahwa rendemen tertinggi didapatkan pada perlakuan dengan lama waktu ekstraksi adalah 12 menit dengan rasio bahan per pelarut sebanyak $13.75 \mathrm{~g} / 100 \mathrm{ml}$ menghasilkan rendemen sebesar $3.35 \%$ dan untuk rendemen yang terendah didapatkan pada perlakuan dengan lama ekstraksi 3.51 menit dan rasio $13.75 \mathrm{~g} / 100 \mathrm{ml}$ menghasilkan rendemen sebesar $0.68 \%$. Diduga pada kondisi ini jumlah pelarut yang digunakan tidak dapat mengekstrak bahan secara sempurna. Menurut Bustan et al., (2008) menyatakan bahwa yang mempengaruhi hasil rendemen adalah faktor intensitas cahaya, penanganan, ukuran partikel daun setelah dipanen, pre perlakuan, umur jenis larutan pengekstrak, lama waktu ekstraksi, suhu ekstraksi, dan proses ekstraksi yang digunakan. Rendemen sebesar 3.35\% diperoleh karena pada metode sonikasi, terjadi kavitasi saat diberi perlakuan gelombang ultrasonik untuk memecah dinding sel bahan. Kavitasi adalah proses pembentukan gelembung-gelembung mikro (microbubbles) karena meningkatnya tekanan pada saat ekstraksi sebagai akibat dari adanya gelombang ultrasonik. Gelembunggelembung ini tidak stabil sehingga mudah pecah ketika gelembung tersebut mencapai volume yang tidak cukup lagi menyerap energi (Manasika dan Wijanarko, 2015).

Pecahnya gelembung-gelembung ini melibatkan energi yang besar dan menghasilkan efek panas yang membantu kontak antara pelarut dan bahan dalam ekstraksi sehingga hasil ekstraksi lebih maksimal. Efek mekanik dari metode sonikasi dapat meningkatkan penetrasi pelarut ke dalam sel bahan serta meningkatkan transfer massa sehingga waktu yang dibutuhkan untuk pemecahan sel hanya beberapa menit. Berdasarkan penjelasan tersebut, dapat dikatakan proses ekstraksi menggunakan gelombang ultrasonik akan meningkatkan rendemen ekstrak yang dihasilkan (Manasika dan Wijanarko, 2015).

Berdasarkan penelitian Amaliawati (2015) daun pepaya yang diberi perlakuan perebusan selama lima menit dengan penambahan tanah menghasilkan rendemen yang paling tinggi yaitu $11.53 \%$ pada ekstrak air dan rendemen yang paling rendah yaitu pada daun pepaya yang direbus selama tiga menit dengan penambahan tanah pada ekstrak etanol sebesar 4.05\% lebih besar dari penelitian ini.

\section{Total Fenol Ekstrak Daun Pepaya}

Data hasil perlakuan terhadap respon total fenol diperoleh pada Tabel 1 yaitu total fenol tertinggi didapatkan pada perlakuan dengan lama waktu ekstraksi 12 menit dengan rasio bahan per pelarut sebanyak 13.75g/100 ml menghasilkan total fenol 
sebesar $55.2083 \mathrm{mgGAE} / \mathrm{g}$ dan untuk total fenol yang terendah didapatkan pada perlakuan dengan lama ekstraksi 3.51 menit dan rasio $13.75 \mathrm{~g} / 100 \mathrm{ml}$ menghasilkan total fenol sebesar $38.9751 \mathrm{mgGAE} / \mathrm{g}$. Hasil analisa ragam menunjukkan bahwa perlakuan rasio berat bahan per pelarut dan lama ekstraksi memberikan pengaruh nyata $(\mathrm{a}=0.05)$ terhadap kadar total fenol ekstrak daun pepaya. Semakin banyak pelarut yang ditambahkan maka semakin besar kemampuan pelarut untuk melarutkan bahan sehingga semakin banyak komponen bahan yang dapat terekstrak oleh pelarut. Komponen bahan yang terekstrak akan terus meningkat hingga larutan menjadi jenuh, setelah melewati titik jenuh larutan, tidak akan terjadi peningkatan hasil ekstraksi dengan penambahan pelarut (Siregar, 2005).

Menurut Handayani dan Sriherfyna (2016) bahwa larutan sudah memasuki titik jenuh sehingga tidak dapat menghasilkan ekstrak lebih banyak lagi. Salah satu faktor yang mempengaruhi hal ini adalah proses kavitasi pada ektraksi metode ultrasonik. Saat suhu meningkat, terjadi peningkatan jumlah gelembung dalam cairan namun intensitas dari pemecahan atau terjadinya kavitasi tereduksi karena tekanan uap sehingga kavitasi yang terjadi semakin menurun. Selain itu diduga masih ada partikel gumpalan yang tidak larut dalam air namun dapat mengikat senyawa yang dapat larut dalam air hal ini menyebabkan perbedaan hasil komponen senyawa bioaktif yang dihasilkan.

\section{Aktivitas Antioksidan $\left(\mathrm{IC}_{50}\right)$ Ekstrak Daun Pepaya}

Data hasil perlakuan terhadap respon aktivitas antioksidan diperoleh nilai tertinggi $\mathrm{IC}_{50}$ sebesar $124.81 \mathrm{ppm}$ pada perlakuan lama waktu ekstraksi adalah 12 menit dengan rasio berat bahan per pelarut sebanyak $13.75 \mathrm{~g} / 100$ $\mathrm{ml}$ dan untuk aktivitas antioksidan yang terendah menghasilkan $\mathrm{IC}_{50}$ sebesar 473.15 ppm didapatkan pada perlakuan lama ekstraksi 3.51 menit dan rasio $13.75 \mathrm{~g} / 100 \mathrm{ml}$. Perhitungan yang digunakan dalam penentuan aktivitas penangkap radikal adalah nilai $\mathrm{IC}_{50}$. Nilai tersebut menggambarkan besarnya konsentrasi senyawa uji yang dapat menangkap radikal sebesar $50 \%$. Nilai IC $\mathrm{IC}_{50}$ semakin kecil nilai $\mathrm{IC}_{50}$ maka senyawa uji tersebut akan semakin efektif sebagai penangkap radikal. Pengujian aktivitas antioksidan ekstrak daun pepaya menggunakan radikal bebas 1,1-diphenyl-2picrylhydrazil (DPPH).
Berdasarkan penelitian Yuliantari et al. (2017) suhu ekstrak semakin tinggi dapat mempengaruhi senyawa target. Pada suhu $45^{\circ} \mathrm{C}$ merupakan perlakuan yang terbaik, tetapi pada suhu $55^{\circ} \mathrm{C}$ senyawa target yang dihasilkan cenderung menurun. Aktivitas antioksidan pada ekstrak daun pepaya dipengaruhi oleh kadar total fenol dan flavonoid (Perwiratami et al., 2014). Aktivitas antioksidan yang dihitung dengan persen inhibisi akan semakin meningkat dengan meningkatnya kadar total fenol dan kadar flavonoid ekstrak daun pepaya, begitu pula sebaliknya nilai persen inhibisi ekstrak daun pepaya akan semakin menurun apabila kadar total fenol dan flavonoid menurun.

Uji aktivitas antioksidan dari ekstrak daun pepaya dengan pelarut air dan etanol $70 \%$ dapat dikatakan sangat lemah, karena nilai IC IC $_{50}$ berada diatas 200 ppm. Semakin kecil nilai $\mathrm{IC}_{50}$ menunjukkan kemampuan antioksidan yang lebih baik dalam menangkal radikal bebas. Hasil uji aktivitas antioksidan menunjukkan bahwa nilai $\mathrm{IC}_{50}$ yang terbaik terdapat pada sampel ekstrak dengan perebusan tiga menit pada pelarut etanol $70 \%$ yaitu sebesar $528.495 \mathrm{ppm}$. Nilai $\mathrm{IC}_{50}$ diperoleh melalui persamaan linier antara persen inhibisi dengan konsentrasi sampel. Semakin rendah nilai $\mathrm{IC}_{50}$ maka daya hambat ekstrak terhadap radikal bebas semakin tinggi. Molyneux (2004) menggolongkan aktivitas antioksidan berdasarkan nilai $\mathrm{IC}_{50}$ yang diperoleh, yaitu sangat kuat $\left(\mathrm{IC}_{50}>100 \mathrm{ppm}\right)$, sedang (100 ppm s/d 150 ppm), lemah (150 ppm s/d $200 \mathrm{ppm})$, dan sangat lemah $\left(\mathrm{IC}_{50}>200 \mathrm{ppm}\right)$.

\section{Analisis Response Surface Rendemen}

Hasil analisis response surface dilakukan untuk mengetahui model yang sesuai berdasarkan sequential model SS, Uji Lack Fit, dan Adjusted R-Square. Hasil analisis model yang disarankan adalah model kuadratik dengan pertimbangan Sequential model SS p_value 0.0211 kurang dari nilai $\alpha=0.05$ (signifikan), artinya model ini sesuai. Uji Lack Fit p_value 0.1912 lebih besar dari nilai $a=0.05$ (tidak signifikan), yang berarti tidak terdapat ketidaksesuaian (lack fit) model dan nilai Adjusted R-Square pada model kuadratik juga cukup besar yaitu 0.6065 atau sebesar $60.65 \%$ keragaman rendemen dapat dijelaskan oleh lama waktu ekstraksi dan rasio berat bahan per pelarut, sedangkan $39.35 \%$ sisanya dijelaskan oleh faktor lain yang tidak diteliti. Semakin besar nilai $R$-Square maka model akan semakin baik. 


\section{Analysis of Variance (ANOVA) Terhadap Rendemen}

Hasil Analysis of Variance (ANOVA) diketahui bahwa nilai $\mathrm{F}(\mathrm{F}$ value $)=4.7$ dan nilai probabilitas (p_value) $=0.0335$ lebih kecil dari angka signifikansi 0.05 (lebih kecil nilai alpha $5 \%)$. Hal ini menunjukkan bahwa rendemen yang dihasilkan terdapat perbedaan dan perbedaan rendemen yang dihasilkan merupakan respon terhadap ragam perlakuan yang meliputi lama waktu sonikasi dan rasio berat bahan per volume pelarut. Selanjutnya berdasarkan uji parsial untuk tiap variabel pengujian terlihat bahwa pelakuan yang berpengaruh nyata hanya perlakuan lama waktu dan lama waktu kuadrat, sedangkan rasio bahan per pelarut, interaksi lama waktu dengan rasio bahan per pelarut dan rasio bahan per pelarut kuadrat tidak berpengaruh nyata karena $p_{\text {_value }}>\mathrm{a}(0.05)$.

Model persamaan yang dihasilkan adalah model persamaan regresi kuadratik. Berdasarkan analisis regesi polinomial orde 2 maka diperoleh model dugaan untuk rendemen menggunakan Persamaan 1.

$Y_{1}=-2.0026+0.4651 . X_{1}+0.1685 . X_{2}+5.3320$. $X_{1} \cdot X_{2}-0.0193 . X_{1}^{2}-6.7712 . X_{2}^{2}$

Berdasarkan model persamaan regesi tersebut dapat dijelaskan bahwa $\mathrm{Y}$ adalah rendemen, $X_{1}$ adalah lama waktu ekstraksi, dan $X_{2}$ adalah rasio bahan per pelarut dan lama waktu ekstraksi dengan rasio bahan per pelarut berpengaruh sebesar $\mathrm{R}^{2}=77.05 \%$ sisanya adalah faktor lain yang tidak diteliti. Hasil persamaan tersebut menjelaskan bahwa rendemen akan mengalami peningkatan dengan semakin lama waktu ekstraksi, meningkatnya rasio bahan per pelarut dan meningkatnya interaksi waktu dengan rasio bahan per pelarut. Hal tersebut ditunjukkan dengan nilai koefisien regesi yang positif.

Rendemen akan menurun dengan peningkatan kuadrat lama waktu ekstraksi dan kuadrat rasio berat bahan per pelarut. Kontribusi terbesar adalah dari pengaruh interaksi antara waktu dan rasio dimana nilai koefisiennya paling besar yaitu 5.33, artinya setiap meningkatnya 1 satuan interaksi waktu dengan rasio bahan per pelarut akan meningkatkan rendemen sebesar 5.332 satuan dengan asumsi faktor lain tetap.

\section{Analisis Response Surface Total Fenol}

Hasil analisis analisis response surface terhadap total fenol model yang disarankan adalah model kuadratik dengan pertimbangan Sequential model SS p_value 0.0210 kurang $\alpha=0.05$ (signifikan), artinya model ini sesuai. Uji Lack Fit p_value 0.2568 lebih besar a $=0.05$ (tidak signifikan), yang berarti tidak terdapat ketidaksesuaian (lack fit) model, dan nilai Adjusted R-Square pada model kuadratik yaitu 0.5906 atau sebesar $59.06 \%$ keragaman total fenol dapat dijelaskan oleh lama waktu ekstraksi dan rasio bahan per pelarut sedangkan $40.94 \%$, sisanya dijelaskan oleh faktor lain yang tidak diteliti. Nilai ini masih cenderung rendah yang menunjukkan perlu adanya penambahan faktor lain yang mempengaruhi total fenol.

\section{Analysis of Variance (ANOVA) Terhadap Total Fenol}

Salah satu cara untuk mengetahui ada tidaknya pengaruh keragaman perlakuan yaitu waktu sonikasi dan rasio berat bahan per volume pelarut terhadap respon yang dihasilkan yaitu total fenol, dilakukan pengujian Analysis of Variance (ANOVA). Hasil uji ANOVA, didapat nilai $\mathrm{F}=4.46$ dan $p$-value $=0.038$ dan signifikan pada tingkat signifikansi $\alpha=5 \%$ ( $p$-value $=0.038$ lebih kecil dari $\alpha=5 \%)$, artinya terdapat pengaruh keragaman perlakuan waktu sonikasi dan rasio berat bahan per pelarut terhadap respon yang dihasilkan yaitu total fenol. Selanjutnya uji secara parsial untuk tiap variabel menjelaskan bahwa pelakuan yang berpengaruh nyata lama waktu kuadrat, sedangkan perlakuan lama waktu, rasio bahan per pelarut, interaksi lama waktu dengan rasio bahan per pelarut dan rasio bahan per pelarut kuadrat tidak berpengaruh nyata karena $p_{-}$value $>\mathrm{a}$ (0.05).

Nilai Adjusted R-Square pada model kuadratik yaitu 0.5906 atau sebesar 59.06\% keragaman total fenol dapat dijelaskan oleh lama waktu ekstraksi dan rasio bahan per pelarut sedangkan $40.94 \%$ sisanya dijelaskan oleh faktor lain yang tidak diteliti. Nilai $A d-$ equate precision merupakan besarnya sinyal terhadap noise ratio. Pada model ini diperoleh nilai adequate precision sebesar 5.380, nilai ini lebih besar dari 4 sehingga dapat memberikan sinyal yang memadai, sehingga model tersebut dapat digunakan sebagai pedoman design space. Nilai koefisien keragaman (Coeficien Variance/ CV) diperoleh sebesar 7.19\%. Model yang baik memiliki nilai CV yang kecil sekitar $<25 \%$. 
Berdasarkan analisis regesi polinomial orde 2 maka diperoleh model dugaan untuk total fenol sesuai dengan Persamaan 2.

$Y_{2}=20.6989+2.7854 . X 1+1.2744 . X_{2}+0.04556$

$X_{1} \cdot X_{2}-0,1264 \cdot X_{1}^{2}-0,0531 . X_{2}^{2}$

Berdasarkan model persamaan regesi tersebut dapat dijelaskan bahwa $\mathrm{Y}$ adalah rendemen, $\mathrm{X}_{1}$ adalah lama waktu ekstraksi, dan $\mathrm{X}_{2}$ adalah rasio bahan per pelarut dan lama waktu ekstraksi dengan rasio bahan per pelarut berpengaruh sebesar $\mathrm{R}^{2}=76.12 \%$ sisanya adalah faktor lain yang tidak diteliti.

Berdasarkan model diatas dapat disimpulkan bahwa total fenol akan mengalami peningkatan dengan semakin lama waktu ekstraksi, meningkatnya rasio berat bahan per volume pelarut dan meningkatnya interaksi waktu dengan rasio berat bahan per volume pelarut. Hal tersebut ditunjukkan dengan nilai koefisien regresi yang positif. Total fenol akan menurun dengan peningkatan kuadrat lama waktu ekstraksi dan kuadrat rasio berat bahan per volume pelarut. Kontribusi terbesar adalah dari pengaruh lama waktu ekstrasi dengan nilai koefisiennya paling besar yaitu 2.78. Artinya setiap meningkatnya 1 menit waktu ekstraksi akan meningkatkan total fenol sebesar 2.785 mgGAE/g dengan asumsi faktor lain tetap.

Analisis Response Surface Aktivitas Antioksidan Hasil analisis response surface aktivitas antioksidan model yang disarankan adalah model kuadratik dengan pertimbangan Sequential model SS p_value 0.0106 kurang $\mathrm{a}=0.05$ (signifikan), artinya model ini sesuai. Uji Lack Fit p_value 0.2568 lebih besar $\mathrm{a}=0.05$ (tidak signifikan), yang berarti tidak terdapat ketidaksesuaian (lack fit) model, dan nilai Adjusted $R$-Square pada model kuadratik yaitu 0.6804 atau sebesar $68.04 \%$ keragaman aktifitas antioksidan dapat dijelaskan oleh lama waktu ekstraksi dan rasio berat bahan per volume pelarut, sedangkan 31.96\% sisanya dijelaskan oleh faktor lain yang tidak diteliti.

\section{Analysis of Variance (ANOVA) Terhadap Aktivitas Antioksidan \\ Untuk mengetahui ada tidaknya pengaruh keragaman perlakuan yaitu wak- tu sonikasi dan rasio bahan per pelarut ter- hadap respon yang dihasilkan yaitu aktivitas antioksidan, dilakukan pengujian menggu-}

nakan Analisys of Variance (ANOVA). Hasil uji ANOVA diperoleh nilai $\mathrm{F}=6.11$ dan $p$ value $=0.0172$ lebih kecil daripada tingkat signifikansi 0.05 ( $p$-value $=0.0172<\alpha=5 \%)$, Hal ini menunjukkan adanya pengaruh keragaman perlakuan terhadap aktifitas antioksidan. Hasil Uji lebih lanjut secara parsial untuk tiap variabel terlihat bahwa pelakuan yang berperngaruh nyata hanya perlakuan lama waktu ekstraksi, lama waktu ekstraksi kuadrat dan rasio bahan per pelarut kuadrat. Rasio bahan per pelarut dan interaksi lama waktu ekstraksi dengan rasio bahan per pelarut tidak berperngaruh nyata karena p_value > a (0.05).

Nilai Adjusted R-Square pada model kuadratik juga cukup besar yaitu 0.6804 atau sebesar $68.04 \%$ keragaman aktivitas antioksidan dapat dijelaskan oleh lama waktu extraksi dan rasio berat bahan per volume palarut, sedangkan $31.96 \%$ sisanya dijelaskan oleh faktor lain yang tidak diteliti. Nilai adequate precision merupakan besarnya sinyal terhadap noise ratio. Pada model ini diperoleh nilai adequate precision sebesar 6.720, nilai ini lebih besar dari 4 sehingga dapat memberikan sinyal yang memadai, sehingga model tersebut dapat digunakan sebagai pedoman design space. Nilai koefisien keragaman $(\mathrm{CV})$ diperoleh sebesar $17.73 \%$. Model yang baik memiliki nilai CV yang kecil sekitar $<25 \%$.

Model persamaan yang dihasilkan adalah model persamaan regesi kuadratik dengan nilai aktual terlampir. Berdasarkan analisis regesi polinomial orde dua maka diperoleh model dugaan untuk aktivitas antioksidan sesuai dengan Persamaan 3.

$Y=854.9363-55.9643 . X_{1}-31.6943 . X_{2}-0.4634$. $X_{1} \cdot X_{2}+2.1664 . X_{1}^{2}+1.2671 . X_{2}^{2}$

Berdasarkan model pada Persamaan 3, dapat disimpulkan bahwa aktivitas antioksidan akan mengalami penurunan dengan semakin lama waktu ekstraksi, semakin besarnya rasio berat bahan per volume pelarut dan semakin besarnya interaksi lama waktu ekstrasi dengan rasio berat bahan per volume pelarut. Hal tersebut ditunjukkan dengan nilai koefisien regesi yang negatif. Sebaliknya aktivitas antioksidan akan meningkat dengan peningkatan kuadrat lama waktu ekstraksi dan kuadrat rasio berat bahan per volume pelarut. Kontribusi terbesar adalah dari pengaruh lama waktu 
ekstraksi dengan nilai koefisiennya paling besar yaitu 55.96. Artinya, setiap peningkatan 1 menit waktu ekstraksi akan meningkatkan aktifitas antioksidan sebesar 55.96 satuan dengan asumsi faktor lain tetap.

\section{Optimasi Formula Rendemen, Total Fenol, dan Aktivitas Antioksidan $\left(\mathrm{IC}_{50}\right)$ \\ Progam DX-7 akan mengolah semua} variabel respon, dan memberikan beberapa solusi sebagai formula terpilih sesuai dengan target optimasi yang diinginkan. Target optimasi dimaksudkan untuk meminimumkan usaha yang diperlukan atau biaya operasional dan memaksimumkan yang diinginkan. Proses ini diharapkan respon rendemen, total fenol, dan antioksidan yang maksimum. Antioksidan yang maksimum memiliki nilai $\mathrm{IC}_{50}$ yang minimum. Prediksi nilai maksimum yang dihasilkan dengan menggunakan progam DX 7.0 yang disajikan pada Gambar 1 antara lain rendemen $2.895 \%$, total fenol 52.031, dan prediksi nilai minimum yang diperoleh dari antioksidan $\left(\mathrm{IC}_{50}\right)$ adalah 211.894 ppm.

Progam DX 7.0 rancangan RSM telah menyediakan tingkat kepentingan variabel respon yang dapat ditingkatkan dengan memberikan pembobotan yang disebut importance. Pembobotannya dipilih mulai dari $\left.1 \mathrm{(}^{+}\right)$hingga $5(+++++)$ tergantung tingkat kepentingan yang diinginkan. Semakin banyak tanda positif menunjukkan tingkat kepentingan terhadap variabel respon yang semakin tinggi. Pada Tabel 2 menunjukkan variabel-variabel dan respon yang dioptimasi, targetnya, batas minimum dan maksimumnya, serta importance pada tahap optimasi formula.

Pada penelitian ini, ditetapkan waktu dengan kisaran 3.51 menit sampai 20.49 menit merupakan komponen yang dioptimalkan dengan goal in range dengan importance 3 $(+++)$. Selain itu rasio berat bahan per pelarut ditetapkan pada kisaran $4.91 \mathrm{~g} / 100 \mathrm{ml}$ sampai dengan $22.59 \mathrm{~g} / 100 \mathrm{ml}$ merupakan komponen yang dioptimalkan dengan goal in range dengan importance $3(+++)$. Lamanya waktu ektraksi dan rasio berat bahan per volume per larut akan mempengaruhi kualitas kandungan daun pepaya yang dihasilkan, sedangkan rendemen dengan kisaran $0.679 \%$ hingga $3.35 \%$ dan total fenol dengan kisaran $38.975 \%$ hingga 55.208\% merupakan respon yang dioptimalkan dengan goal maximize, sedangkan antioksidan $\left(\mathrm{IC}_{50}\right)$ merupa- kan respon yang dioptimalkan dengan goal minimal dengan kisaran 124.811 ppm hingga 473.149 ppm.

Berdasarkan Tabel 2, solusi formula terpilih yaitu formula dengan kombinasi lamanya waktu ekstraksi 14.36 menit dengan rasio berat bahan per volume pelarut $16.92 \mathrm{~g} / 100 \mathrm{ml}$. Formula ini diprediksi akan memiliki rendemen sebesar $2.895 \%$, total fenol sebesar 50.03 mgGAE/g dan antioksidan $\left(\mathrm{IC}_{50}\right) 211.924$ dengan nilai desirability sebesar 0.794. Hal ini berarti formula tersebut akan menghasilkan produk yang memiliki karakteristik yang sesuai dengan target optimasi sebesar $79.4 \%$.

\section{Verifikasi}

Tahap verifikasi bertujuan untuk melakukan pembuktian terhadap prediksi dari nilai respon solusi kondisi proses optimum yang diberikan oleh Progam DX versi 7.0 dengan rancangan RSM. Pada tahapan verifikasi, nilai respon aktual yang diperoleh dibandingkan dengan nilai respon prediksi yang dihasilkan oleh Progam DX versi 7.0 dengan rancangan RSM. Di samping itu, nilai respon dari setiap solusi formula optimum yang diberikan, progam DX versi 7.0 dengan rancangan RSM juga memberikan confidence interval dan prediction interval untuk setiap nilai respon prediksi pada taraf signifikansi 5\%. Nilai dugaan respon yang baik berada pada kisaran confidence interval (CI) dan prediction interval (PI).

Berdasarkan Tabel 3 solusi yang diperoleh dari perhitungan software Design Expert, titik optimum variabel bebas untuk waktu selama 14.36 menit dan rasio berat bahan per volume pelarut seberat $16.92 \mathrm{~g} / 100 \mathrm{ml}$. Berdasarkan titik optimum untuk variabel bebas lama waktu dan rasio berat bahan per volume pelarut, diperoleh respon optimum untuk rendemen $2.89454 \%$, total fenol $52.03 \mathrm{mgGAE} / \mathrm{g}$, aktivitas antioksidan $\left(\mathrm{IC}_{50}\right) 211.92 \mathrm{ppm}$.

Berdasarkan hasil solusi titik optimum yang dihasilkan software Design Expert, selanjutnya dilakukan validasi model dengan melakukan percobaan sesuai yang disarankan oleh software Design Expert. Percobaan dilakukan sesuai dengan hasil solusi titik optimum tersebut dilakukan pengulangan 5 kali untuk menghindari adanya data pencilan. Setelah diperoleh hasil percobaan dari laboratorium kemudian dibandingkan dengan hasil solusi titik optimum yang dihasilkan software Design Expert. Perbandingan 

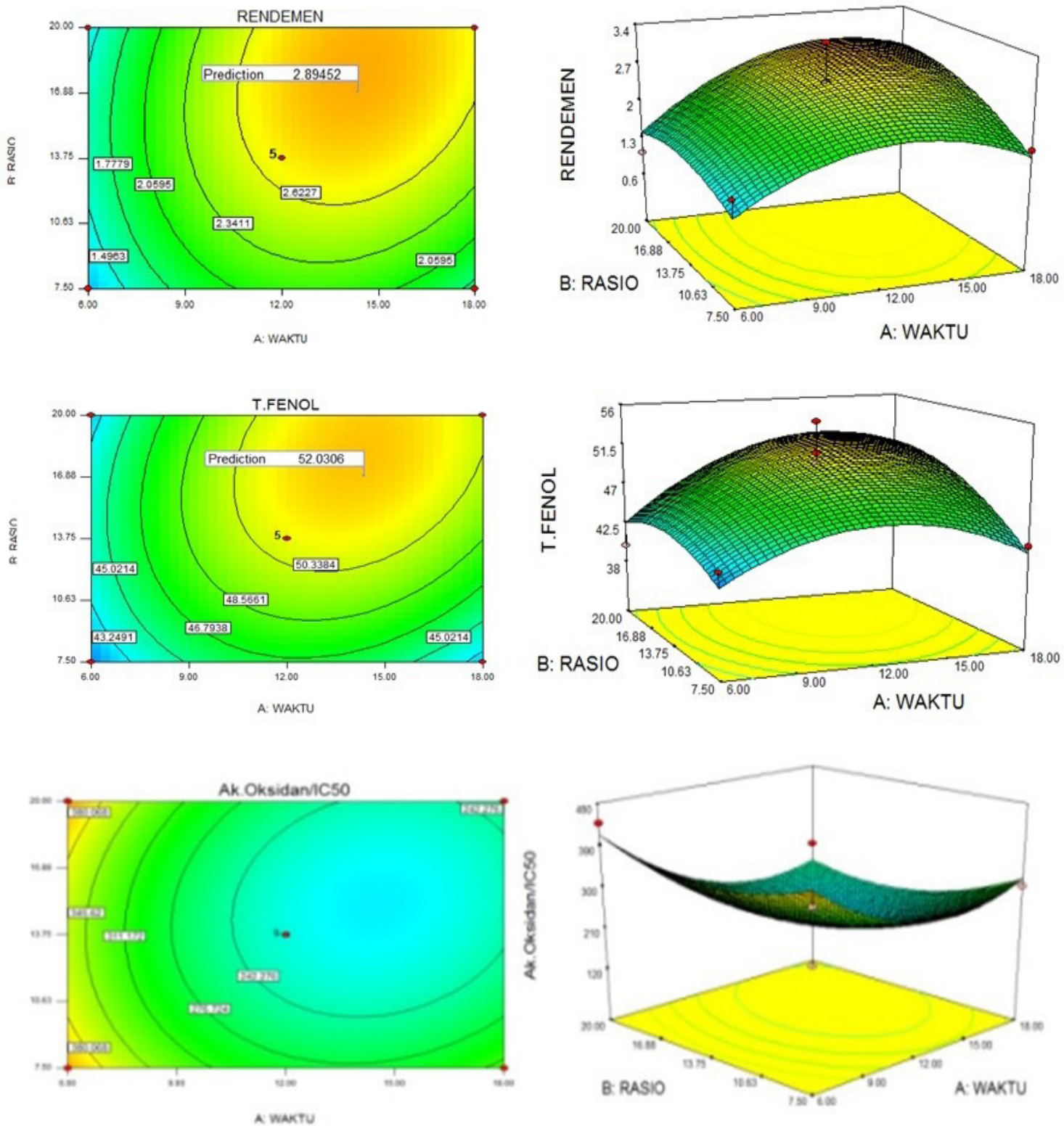

Gambar 1. Grafik kontur dan 3 dimensi hubungan waktu sonikasi, rasio bahan per pelarut dengan rendemen, total fenol, dan aktivitas antioksidan $\left(\mathrm{IC}_{50}\right)$
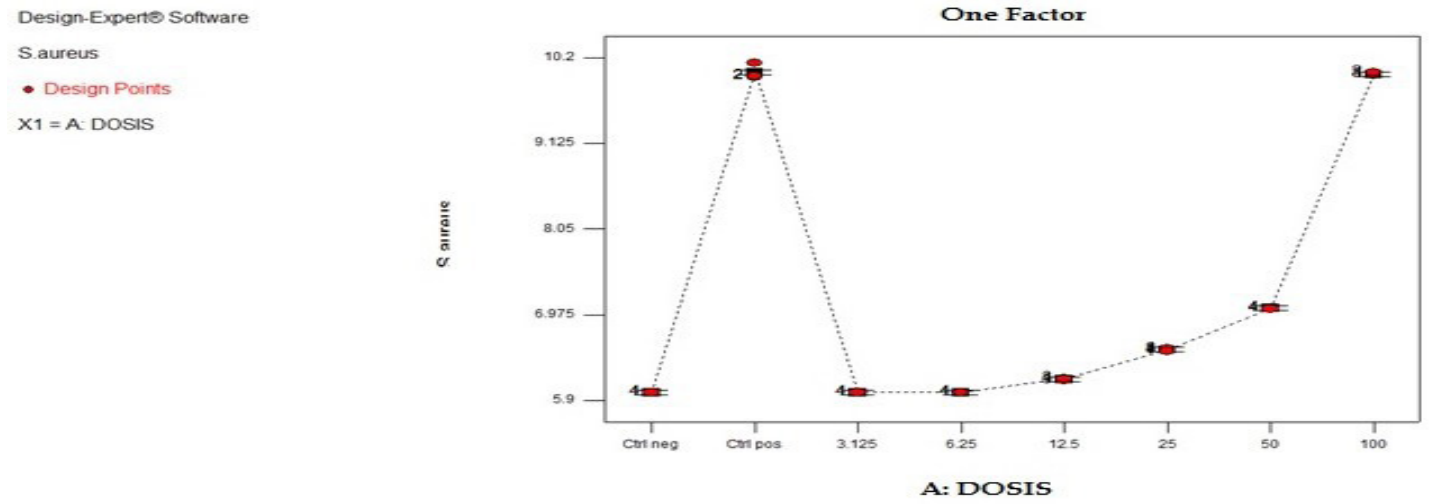

Gambar 2. Grafik respon bakteri Staphylococcus aureus terhadap dosis ekstrak daun pepaya 
Tabel 1. Rendemen, total fenol, aktivitas antioksidan ekstrak daun pepaya

\begin{tabular}{cccccc}
\hline No & $\begin{array}{c}\text { Waktu } \\
\text { (Menit) }=\mathbf{X}_{\mathbf{1}}\end{array}$ & $\begin{array}{c}\text { Rasio } \\
\text { Bahan/pelarut } \\
(\mathbf{g} / \mathbf{1 0 0} \mathbf{~ m l})=\mathbf{X}_{\mathbf{2}}\end{array}$ & $\begin{array}{c}\text { Rendemen } \%= \\
\mathbf{Y}_{\mathbf{1}}\end{array}$ & $\begin{array}{c}\text { Total Fenol } \\
\text { mgGAE/g }=\mathbf{Y}_{2}\end{array}$ & $\begin{array}{c}\text { Akt. Anti } \\
\text { Oksidan } \\
\left(\mathbf{I C}_{50} \mathbf{p p m}\right)=\mathbf{Y}_{3}\end{array}$ \\
\hline 1 & 12.00 & 4.91 & 1.42 & 41.54 & 378.39 \\
2 & 6.00 & 20.00 & 1.02 & 39.83 & 438.72 \\
3 & 6.00 & 7.50 & 1.53 & 43.08 & 378.39 \\
4 & 12.00 & 22.59 & 3.21 & 54.02 & 257.08 \\
5 & 20.49 & 13.75 & 2.22 & 46.67 & 276.29 \\
6 & 12.00 & 13.75 & 3.35 & 55.21 & 124.81 \\
7 & 12.00 & 13.75 & 2.65 & 50.59 & 240.19 \\
8 & 3.51 & 13.75 & 0.68 & 38.98 & 473.15 \\
9 & 12.00 & 13.75 & 2.67 & 51.79 & 221.79 \\
10 & 18.00 & 7.50 & 1.81 & 43.25 & 304.16 \\
11 & 12.00 & 13.75 & 2.29 & 48.03 & 263.23 \\
12 & 12.00 & 13.75 & 2.59 & 48.89 & 263.23 \\
13 & 18.00 & 20.00 & 2.10 & 46.84 & 294.98 \\
\hline
\end{tabular}

Tabel 2. Kriteria optimasi proses ekstrasi, pengujian terhadap respon, dan solutions

\begin{tabular}{|c|c|c|c|c|c|c|}
\hline Name & Goal & $\begin{array}{l}\text { Lower } \\
\text { Limit }\end{array}$ & Upper Limit & $\begin{array}{l}\text { Lower } \\
\text { Weight }\end{array}$ & $\begin{array}{c}\text { Upper } \\
\text { Weight }\end{array}$ & Importance \\
\hline Waktu & Is in range & 3.51 & 20.49 & 1 & 1 & 3 \\
\hline Rasio & Is in range & 4.91 & 22.59 & 1 & 1 & 3 \\
\hline Rendemen & Maximize & 0.679 & 3.350 & 1 & 1 & 3 \\
\hline T.Fenol & Maximize & 38.975 & 55.208 & 1 & 1 & 3 \\
\hline Akt. Oksidan & Minimize & 124.811 & 473.149 & 1 & 1 & 3 \\
\hline \multicolumn{7}{|l|}{ Solutions } \\
\hline Number & $\begin{array}{l}\text { Waktu } \\
\text { (Menit) }\end{array}$ & Rasio & Rendemen & T.Fenol & $\begin{array}{c}\text { Akt. } \\
\text { Oksidan }\end{array}$ & Desirability \\
\hline 1 & 14.36 & 16.92 & 2.894 & 52.031 & 211.924 & $0.794^{*}$ \\
\hline
\end{tabular}

Tabel 3. Solusi titik optimum dan verifikasi dari kriteria terpilih

\begin{tabular}{|c|c|c|c|c|c|}
\hline & \multirow[b]{2}{*}{$\begin{array}{l}\text { Waktu } \\
\text { (menit) }\end{array}$} & \multirow[b]{2}{*}{$\begin{array}{c}\text { Rasio Bahan/ } \\
\text { pelarut } \\
(\mathrm{g} / 100 \mathrm{ml})\end{array}$} & \multicolumn{3}{|c|}{ Respon } \\
\hline & & & $\begin{array}{c}\text { Rendemen } \\
(\%)\end{array}$ & $\begin{array}{l}\text { Total Fenol } \\
\text { (mgGAE/g) }\end{array}$ & $\begin{array}{c}\text { Aktivitas } \\
\text { Antioksidan } \\
\text { IC }_{50}(\mathrm{ppm}) \\
\end{array}$ \\
\hline Prediksi* & 14.36 & 16.92 & 2.89 & 52.0313 & 211.94 \\
\hline Interval Prediksi* & 14.36 & 16.92 & $1.59-4.20$ & $43.34-60.72$ & $73.99-349.82$ \\
\hline Verifikasi** $^{* *}$ & 14.36 & 16.92 & 2.83 & 51.11 & 212.76 \\
\hline $\begin{array}{l}\text { Persentase Perbedaan } \\
\text { dan Verifikasi }\end{array}$ & n Nilai & Respon Prediksi & $1.92 \%$ & $1.77 \%$ & $0.40 \%$ \\
\hline
\end{tabular}


hasil validasi laboratorium dengan hasil solusi titik optimum yang dihasilkan software Design Expert disajikan pada Tabel 3.

Hasil perbandingan rerata rendemen, total fenol, dan aktivitas antioksidan $\left(\mathrm{IC}_{50}\right)$ hasil verifikasi dengan hasil solusi titik optimum yang dihasilkan software Design Expert berturut-turut sebesar $1.92 \%, 1.77 \%$, dan $0.40 \%$. Persentase perbedaan nilai respon rendemen, total fenol, dan aktivitas antioksidan $\left(\mathrm{IC}_{50}\right)$ tidak terlalu besar, dan nilai hasil verifikasi hampir mendekati perhitungan software Design Expert, sehingga perbedaan ini dapat dianggap tidak signifikan dan hasil solusi titik optimum untuk variabel bebas yaitu lama waktu dan rasio berat bahan per volume pelarut yang dihasilkan oleh perhitungan software Design Expert menghasilkan respon rendemen, total fenol, dan aktivitas antioksidan $\left(\mathrm{IC}_{50}\right)$ yang optimum dan benar. Perbedaan nilai prediksi dengan nilai penelitian yang tidak lebih dari 5\% menunjukkan bahwa model tersebut cukup tepat (Wangtueai dan Noomhorm, 2009).

\section{Uji Anti Bakteri}

Pada tahap kedua, penelitian dilakukan untuk mengetahui pengaruh dosis ekstrak daun pepaya terhadap aktivitas antibakteri. Rancangan percobaan untuk mengetahui pengaruh dosis ekstrak daun pepaya terhadap aktivitas antibakteri menggunakan General Factor Design, dengan menggunakan satu faktor yang terdiri dari 6 level dosis hasil ekstrak daun pepaya, kontrol negatif dan positif. Dosis ekstrak daun pepaya level satu $=3.125 \mathrm{mg} / \mathrm{ml}$; level dua $=6.25 \mathrm{mg} / \mathrm{ml}$; level tiga $=12.5 \mathrm{mg} / \mathrm{ml}$; level empat $=25 \mathrm{mg} / \mathrm{ml}$; level lima $=50 \mathrm{mg} / \mathrm{ml}$; level enam $=100 \mathrm{mg} / \mathrm{ml}$, dan kontrol positif berupa kertas cakram berisi ampisilin $10 \mu \mathrm{g}$ untuk bakteri Staphylococcus aureus (oxoid), kertas cakram berisi kloramfenikol $30 \mu \mathrm{g}$ untuk Escherichia coli, kontrol negatif berupa aquadest steril.

\section{Analysis of Variance (ANOVA) Staphylo- coccus aureus}

Hasil Analysis of Variance (ANOVA), menunjukkan nilai $\mathrm{F}=7387.32$ dan $p$-value (nilai probabilitas) $=0.0001$ signifikan pada tingkat signifikasi $a=0.05$. Hasil Analysis of Variance (ANOVA), menunjukkan adanya pengaruh ragam dosis ekstrak daun pepaya terhadap respon perkembangan bakteri Staphylococcus aureus.

Berdasarkan hasil uji beda lebih lanjut menunjukkan bahwa dosis (konsentrasi) ekstrak daun pepaya mulai $12.5 \mathrm{mg} / \mathrm{ml}, 25$ $\mathrm{mg} / \mathrm{ml}, 50 \mathrm{mg} / \mathrm{ml}, 100 \mathrm{mg} / \mathrm{ml}$ berpengaruh

Tabel 4. Analysis of variance (ANOVA)

\begin{tabular}{cccccc}
\hline Source & Sum of Squares & $d f$ & $\begin{array}{c}\text { Mean } \\
\text { Squares }\end{array}$ & F Value & P-Value \\
\hline Model & 64.85 & 7 & 9.26 & 7387.32 & $<0.0001^{*}$ \\
Dosis & 64.85 & 7 & 9.26 & 7387.32 & $<0.0001$ \\
Pure Error & 0.020 & 16 & $1.254 \mathrm{E}-003$ & & \\
Cor Total & 64.87 & 23 & & &
\end{tabular}

₹ The model F-value of 7387.32 implies the model is significant. There is only a $0.01 \%$ chance that a "model F-Value" this large could occur due to noise

Tabel 5. Analysis of variance (ANOVA)

\begin{tabular}{cccccc}
\hline Source & Sum of Squares & $d f$ & $\begin{array}{c}\text { Mean } \\
\text { Squares }\end{array}$ & F Value & P-Value \\
\hline Model & 12.81 & 7 & 1.83 & 15684.40 & $<0.0001^{*}$ \\
Dosis & 12.81 & 7 & 1.83 & 15684.40 & $<0.0001$ \\
Pure Error & $1.867 \mathrm{E}-003$ & 16 & $1.167 \mathrm{E}-004$ & & \\
Cor Total & 12.81 & 23 & & &
\end{tabular}

* The model F-value of 15684.40 implies the model is significant. There is only a $0.01 \%$ chance that a "model F-Value" this large could occur due to noise 
terhadap perkembangan Staphylococcus aureus, sedangkan pada dosis (konsentrasi) ekstrak daun pepaya $3.125 \mathrm{mg} / \mathrm{ml}$ dan 6.25 $\mathrm{mg} / \mathrm{ml}$ tidak berpengaruh terhadap perkembangan bakteri Staphylococcus aureus. Hasil uji beda pengaruh dosis ekstrak daun pepaya terhadap perkembangan bakteri Staphylococcus aureus antara dosis tertinggi yaitu 100 $\mathrm{mg} / \mathrm{ml}$ dan kontrol positif (ampisilin $10 \mu \mathrm{g}$ ) tidak menunjukan perbedaan (nilai probabilitas 0.4315 dan lebih besar dari 0.05 atau $a=5 \%)$. Dengan demikian, dapat disimpulkan bahwa dosis ekstrak daun pepaya dapat mempengaruhi perkembangan bakteri staphylococcus aureus mulai dari dosis $12.5 \mathrm{mg} / \mathrm{ml}$.

\section{Respon Bakteri Staphylococcus aureus Terhadap Dosis Ekstrak Daun Pepaya}

Uji antibakteri ini dilakukan untuk mengetahui potensi aktivitas antibakteri pada ekstrak daun pepaya. Pada penelitian ini, ekstrak daun pepaya diujikan terhadap bakteri Staphylococcus aureus sebagai bakteri gram positif dengan menggunakan metode difusi cakram. Metode cakram kertas yaitu meletakkan cakram kertas yang telah direndam larutan uji di atas media padat yang telah diinokulasi dengan bakteri. Setelah diinkubasi, pertumbuhan bakteri diamati untuk melihat ada tidaknya daerah hambatan di sekeliling cakram (Mulyadi et al., 2013). Hasil penelitian menunjukkan bahwa ekstrak daun pepaya dalam berbagai level memberikan pengaruh sangat nyata (nilai probabilitas < 0.001) terhadap diameter hambat bakteri Staphylococcus aureus yang dapat dilihat pada Gambar 2 yang menunjukkan respon Staphylococcus aureus terhadap dosis ekstrak daun pepaya. Faktor-faktor yang berpengaruh pada aktivitas zat antibakteri adalah $\mathrm{pH}$, suhu stabilitas senyawa, jumlah bakteri yang ada, lamanya inkubasi, dan aktivitas metabolism bakteri (Brooks et al., 2013).

Berdasarkan Gambar 2 ini dapat disimpulkan bahwa ekstrak daun pepaya mempunyai potensi untuk menghambat/ menahan perkembangan bakteri Staphylococcus aureus. Penelitian ini sejalan dengan penelitian Tuntun (2016) pada bakteri Staphylococcus aureus, konsentrasi ekstrak daun pepaya 10\% dan $20 \%$ belum dapat menghambat pertumbuhan bakteri Staphylococcus aureus, sedangkan pada konsentrasi 30\% sampai 100\% mampu menghambat pertumbuhan bakteri Staphylococcus aureus dengan rata-rata diameter zona 7.9-13.2 mm. Menurut Baskaran et al. (2012) ekstrak daun pepaya juga mengandung senyawa yang memiliki aktivitas sebagai antibakteri seperti flavonoid, alkaloid karpain, enzim papain dan tanin. Flavonoid yang bersifat lipofilik akan merusak membran, sehingga permeabilitas akan meningkat dan mengganggu metabolisme bakteri. Harborne dan Williams (2000) menyatakan bahwa alkaloid dapat mengganggu terbentuknya komponen penyusun peptidoglikan pada bakteri, sehingga lapisan dinding sel tidak terbentuk secara utuh dan menyebabkan kematian pada bakteri. Selain itu, papain yang merupakan enzim proteolitik juga memiliki efek bakterisid dan bakteriostatik, sehingga menghambat pertumbuhan baik bakteri positif maupun negatif (Sulianti et al., 2012). Efek antimikroba tannin yaitu dengan menginaktivasi adhesin mikroba dan menginaktivasi enzim hidrolitik seperti protease dan karbohidrolase, serta menghambat enzim pada protein transpor selubung (Sung et al., 2012).

\section{Analysis of Variance (ANOVA) Escherichia coli (oxoid)}

Berdasarkan Tabel 5, ANOVA, menunjukkan nilai $\mathrm{F}=15684.40$ dan $p$-value (nilai probabilitas) $=0.0001$ signifikan pada tingkat signifikasi 0.05. Hasil ANOVA, menunjukkan adanya pengaruh ragam dosis ekstrak daun pepaya terhadap respon perkembangan bakteri Escherichia coli (oxoid).

Berdasarkan hasil uji beda lebih lanjut menunjukkan bahwa dosis (konsentrasi) ekstrak daun pepaya mulai $25 \mathrm{mg} / \mathrm{ml}, 50$ $\mathrm{mg} / \mathrm{ml}, 100 \mathrm{mg} / \mathrm{ml}$ berpengaruh terhadap perkembangan Escherichia coli, sedangkan pada dosis (konsentrasi) ekstrak daun pepaya $3.125 \mathrm{mg} / \mathrm{ml}, 6.25 \mathrm{mg} / \mathrm{ml}$, dan $12.5 \mathrm{mg} /$ $\mathrm{ml}$ tidak berpengaruh terhadap perkembangan bakteri Escherichia coli. Hasil uji beda pengaruh dosis ekstrak daun pepaya terhadap perkembangan bakteri Escherichia coli antara dosis tertinggi yaitu $100 \mathrm{mg} / \mathrm{ml}$ dan kontrol positif (kloramfenikol) menunjukan pengaruh yang nyata (nilai probabilitas 0.0001 dan lebih kecil dari 0.05 atau $a=5 \%$ ). Dengan demikian dapat disimpulkan bahwa dosis ekstrak daun pepaya dapat mempengaruhi perkembangan bakteri Escherichia coli mulai dari dosis $25 \mathrm{mg} / \mathrm{ml}$. 


\section{Respon Bakteri Escherichia coli Terhadap Dosis Ekstrak Daun Pepaya}

Uji antibakteri ini dilakukan untuk mengetahui potensi aktivitas antibakteri pada ekstrak daun pepaya. Pada penelitian ini, ekstrak daun pepaya diujikan terhadap bakteri Escherichia coli sebagai bakteri negatif yang diujikan dengan menggunakan metode difusi cakram. Metode cakram kertas yaitu meletakkan cakram kertas yang telah direndam larutan uji di atas media padat yang telah diinokulasi dengan bakteri. Setelah diinkubasi, pertumbuhan bakteri diamati untuk melihat ada tidaknya daerah hambatan disekeliling cakram (Mulyadi et al., 2013). Hasil penelitian menunjukkan bahwa ekstrak daun pepaya dalam berbagai level memberikan pengaruh sangat nyata (nilai $p<0.001$ ) terhadap diameter hambat bakteri Escherichia coli yang dapat dilihat pada Gambar 3 .

Berdasarkan Gambar 3, dapat disimpulkan bahwa ekstrak daun pepaya mempunyai potensi untuk menghambat/menahan perkembangan bakteri Escherichia coli (oxoid). Hasil penelitian ini sejalan dengan hasil penelitian Anggrahini et al., (2013), yaitu tidak ada zona hambat pada konsentrasi $10 \%$, dan didapatkan zona hambat pertumbuhan bakteri Escherichia coli oleh ekstrak daun pepaya mulai dari konsentrasi $25 \%$ hingga $100 \%$. Semakin tinggi konsentrasi ekstrak daun pepaya, maka semakin besar zona hambat yang terbentuk. Besarnya diameter zona hambat yang terbentuk disebabkan kandungan zat antibakteri yang lebih banyak pada konsentrasi yang lebih tinggi. Rata-rata diameter zona hambat yang terbentuk oleh ekstrak daun pepaya terhadap bakteri Escherichia coli lebih kecil dibandingkan terhadap bakteri Staphylococcus aureus. Hal ini disebabkan bakteri Escherichia coli merupakan bakteri gram negatif, dimana dinding selnya mengandung lipid lebih banyak (11$22 \%)$ daripada bakteri gram positif (1-4\%). Kandungan lipid yang tebal pada bakteri Escherichia coli menyebabkan sulit masuknya ekstrak daun pepaya kedalam sel bakteri, sehingga didapatkan zona hambat yang lebih kecil jika dibandingkan bakteri Staphylococcus aureus.

Menurut Martiasih et al., (2015) setiap jenis bahan ekstrak memiliki kemampuan yang berbeda dalam menghambat pertumbuhan bakteri, hal ini diduga karena senyawa aktif pada tiap jenis ekstrak telah terbagi-bagi saat ekstraksi. Pengaruh ini dapat bersifat aditif atau sinergis di antara senyawa yang terkandung dalam ekstrak kasar. Selain itu, hal ini juga kemungkinan ditimbulkan oleh resistensi dari bakteri terhadap substansi bioaktif, kadar substansi aktif serta jumlah inokulum bakteri atau kepadatan bakteri uji. Di samping itu, ditemukan adanya ekstrak yang kurang efektif dalam menghambat bakteri, karena difusi bahan aktif pada medium yang berlangsung lambat dan rendahnya konsentrasi kandungan zat aktif, sehingga ekstrak tersebut tidak dapat menghambat bakteri secara optimal.

\section{SIMPULAN}

Berdasarkan hasil analisis dapat disimpulkan bahwa optimasi dari kombinasi rasio berat bahan per volume pelarut dan lama waktu ekstraksi daun pepaya $16.92 \mathrm{~g} / 100$ $\mathrm{ml}$ dan 14.36 menit dapat menghasilkan tiga respon yang optimum antar lain rendemen sebesar $2.89 \%$, total fenol $50.03 \mathrm{mgGAE} / \mathrm{g}$, dan antioksidan 211.924 ppm. Ekstrak daun pepaya mampu menghambat perkembangan bakteri Staphylococcus aureus dan Escherichia coli. Penelitian selanjutnya, proses penyaringan larutan hasil ekstrak daun pepaya perlu dilakukan lebih dari satu kali agar dapat menghasilkan rendemen, total fenol, dan antioksidan sesuai dengan yang diharapkan.

\section{DAFTAR PUSTAKA}

Amaliawati, D., 2015. Aktivitas Antioksidan Ekstrak Daun Pepaya (Carica Papaya L.) Var Kalina dengan Perlakuan Tanah Lempung. Skripsi. IPB, Bogor

Anggrahini, D, N, D., Roza, R, M., Fitmawati. 2013. Aktivitas antibakteri Ekstrak daun pepaya (Carica papaya L.) terhadap Escherichia coli dan Salmonella typhi. Dilihat 20 Agustus 2018. < https://repository.unri.ac.id/xmlui/ bitstream/handle/123456789/2397/ Karya \% 20Ilmiah\%20Dian \% 20\% 20 ND \% 20Anggraini \% 2011\%2001\%20 2013.pdf? sequence $=1>$

Astuti, D, S. 2009. Efek ekstrak etanol 70\% daun pepaya (Carica papaya L.) terhadap aktivitas AST \& ALT pada tikus 
galur wistar setelah pemberian obat tuberkulosis. Dilihat 20 Agustus 2018. <https:// santidaswety.files.wordpress.com/2012/01/skripsi-santidwi-astuti-11051968-a.pdf>

Ayoola, G, -A., Coker, H, A, -B., Adesegun, S, -A., Adepoju-Bello, A, -A., Obaweya, -K., Ezennia, E, -C., Atangbayila, T, -O., 2008. Phytochemical screening and antioxidant activities of some selected medicine plant used for malaria therapy in southwestern nigeria. Tropical Journal of Pharmaceutical Research. 7(3), 1019-1024. http://dx.doi. org/10.4314/tjpr.v7i3.14686

Baskaran, -C., Bai, V, -R., Velu, -S., Kumaran, -K. 2012. The efficacy of Carica papaya leaf extract on some bacterial and a fungal strain by well diffusion method. Asian Pacific Journal of Tropical Disease. 2(2), 658-662. https://doi. org/10.1016/S2222-1808(12)60239-4

Brooks, G, F., Carroll, K, C., Butel, J, S., Morse, S, A., Mietzner, T, A., 2013. Medical Microbiology. McGraw-Hill, USA

Bustan, M, -D., Febriyani, -R., Pakpahan, -H., 2008. Pengaruh waktu ekstraksi dan ukuran partikel terhadap oleoresin jahe yang diperoleh dalam berbagai jumlah pelarut. Jurnal Teknik Kimia. 15 (4), 16-26. http://jtk.unsri.ac.id/index.php/jtk/article/view/55

Buxton, R., 2007. Desain Expert 7 Introduction. Dilihat 10 Agustus 2018. <https://www.lboro.ac.uk/media/ wwwlboroacuk/content/mlsc/downloads/Design\%20Expert\%207.pdf>

Cho, S, -M., Kwak, K, -S., Park, D, -C., Gu, Y, -S., Ji, C, -I., Jang, D, -H., Lee, Y, -B., Kim, S, -B., 2004. Processing optimation and functional properties of gelatin from shark (Isurus oxyrinchus) cartilage. Food Hydrocolloids, 18(4), 573579. https://doi.org/10.1016/j.foodhyd.2003.10.001

Gaedcke, F., Steinhoff, B., Blasius, H., 2003. Herbal Medicine Product. CRC Press, USA

Gamulle, -A., Ratnasooriya, W, -D., Jayakody, -J., Fernando, -C., Udagama, P, -V., 2012. Trombocytosis and anti-inflamatory properties, and toxicological evaluation of Carica papaya mature leaf concentrate in a murine model. OIJMPR. 1(2), 21-30. https:/ / www.researchgate.net/profile/Preethi_Udagama2/
publication/251237485_Thrombocytosis_and_Anti-inflammatory_Properties_and_Toxicological_Evaluation_of_Carica_papaya_Mature_ Leaf_Concentrate_in_a_Murine_ ModelLinkEditRe-order_section/ links / 0a85e537b53ec86b63000000/ Thrombocytosis-and-Anti-inflammatory-Properties-and-ToxicologicalEvaluation-of-Carica-papaya-MatureLeaf-Concentrate-in-a-Murine-ModelLinkEditRe-order-section.pdf

Handayani, -H., Sriherfyna, F, -H., 2016. Ekstraksi antioksidan daun sirsak metode ultrasonic bath (kajian rasio bahan:pelarut dan lama ekstraksi) antioxidant extraction of soursop leaf with ultrasonic bath (study of material:solvent ratio and extraction time). Jurnal Pangan dan Agroindustri. 4(1), 262-272

Harborne, J, -B., Williams, C, -A., 2000. Advances in flavonoid research since 1992. Phytochemistry. 55(6), 481-504. https://doi.org/10.1016/S00319422(00)00235-1

Manasika, -A., Widjanarko, S, -B., 2015. Ekstraksi pigmen karotenoid labu kabocha menggunakan metode ultrasonik (kajian rasio bahan:pelarut dan lama ekstraksi). Jurnal Pangan dan Agroindustri. 3 (3), 928-938.

Martiasih, -M., Sidharta, B, B, -R., Atmodjo, P, -K., 2015. Aktivitas antibakteri ekstrak biji pepaya (Carica papaya L.) terhadap Escherichia coli dan Streptococcus pyogenes. E-jurnal Universitas Tama Jaya Yogyakarta. http:/ / e-journal.uajy. ac.id/4840/1/jurnal.pdf.

Molyneux, P., 2004. The use of the stable free radical diphenylpicryl-hydrazyl (DPPH) for estimating antioxidant activity. Songklanakarin Journal of Science and Technology 26(2), 211-219. DOI: 10.1287/isre.6.2.144.

Mulyadi, -M., Wuryanti, -W., Ria, P, -S., 2013. Konsentrasi hambat minimum (KHM) kadar sampel alang-alang (Imperata cylindrica) dalam etanol melalui metode difusi cakram. 20(3), 35-42. https:// doi.org/10.14710/jksa.20.3.130-135

Perwiratami, -C., Suzery, -M., Cahyono, -B., 2014. Korelasi total fenolat dan total flavonoid dengan antioksidan dari beberapa sediaan ekstrak buah tanjung (Mimusoup elengi). Chemistry 
Progress. 7(1), 34-38. https://ejournal. unsrat.ac.id/index.php/chemprog/ article/view/4853/4378

Rahmat, -A., Rosli, -R., l'zzah, Wan Mohd. Zain, W, -N., Endrini, -S., Sani, A, -H., 2002. Antiproliferative activity of pure lycopene compared to both extracted lycopene and juice from watermelon (Citrullus vulgaris) and pepaya (Carica papaya) on human breast and liver cancer cell line. Journal of Medical Sciences. 2(2), 55-58. DOI: 10.3923/ jms.2002.55.58

Seigler, D, -S., Pauli, G, -F., Nahrstedt, -A., Leen, -R., 2002. Cyanogenic allosides and glucosides from Passiflora edulis and Carica papaya. Phytochemistry. 60(8), 873-882. https://doi.org/10.1016/ S0031-9422(02)00170-X

Siregar, E, D, M., 2005. Perlakuan Jenis Pakan Alami pada Daun Sirsak dan Teh. Skripsi. IPB. Bogor

Sulianti, T., Djauhari, N., Nursasongko, B., 2012. Perbedaan Efek Antimikroba $\mathrm{Pa}$ pacarie dan Papain terhadap Streptococcus mutans-in Vitro. Tesis. Universitas Indonesia, Jakarta

Sung, S, -H., Kim, K, -H., Joen, B, -T., Cheong, S, -H., Park, J, -H., Kim, D, -H., Kweon, H, -J., Moon, S -H., 2012. Antibacterial and antioxidant activities of tannins extracted from agricultural byproducts. Journal of Medicinal Plants Research. 6(15), 3072-3079. https:// doi. org/10.5897/JMPR11.1575

Suresh, -K., Deepa, -P., Harisaranraj, -R., Achudhan, V, -V., 2008. Antimicrobial and phytochemical investigation of the leaves of Carica papaya L., Cynodon dactylon (L.) Pers., Euphorbia hirta L., Melia azedarach L. and Psidium guajava L. Ethnobotanical Leaflets. 12, 1184-1191. https:/ / pdfs.semanticscholar.org/d3 b8/1025ca493972d0cccf370f5ca4f5187c $5 \mathrm{c} 45 . \mathrm{pdf}$

Tuntun, -M., 2016. Uji efektivitas ekstrak daun pepaya (Carica papaya L.) terhadap pertumbuhan bakteri Escherichia coli dan Staphylococcus aureus. Jurnal Kesehatan. 7(3), 497-502. http://www. ejurnal.poltekkes-tjk.ac.id/index. $\mathrm{php} / \mathrm{JK} /$ article/view/235/221

Umam, M, -F., Utami, R., Widowati, E., 2012. Kajian karakteristik minuman sinbiotik pisang kepok (Musa paradisiaca forma typical) dengan menggunakan starter Lactobacillus acidophillus IFO 13951 dan Bifidobacterium longum ATCC 15707. Jurnal Teknosains Pangan. 1(1), 2-11. https://jurnal.uns.ac.id/teknosainspangan/article/view/4176

Waluyo, L., 2004. Mikrobiologi Umum. UMM Press, Malang

Wangtueai, S., Noomhorm, A., 2009. Processing optimation and characterization of gelatin from lizardfish (Saurida spp) scales. LWT- Food Science and Technology. 42(4), 825-834. https://doi. org/10.1016/j.lwt.2008.11.014

Yuliantari, N, W, -A., Widarta, I, W, -R., Permana, I, D, G, -M., 2017. Pengaruh suhu dan waktu ekstraksi terhadap kandungan flavonoid dan aktivitas antioksidan daun sirsak (Annona muricata L.) menggunakan ultrasonik. Media Ilmiah Teknologi Pangan. 4(1), 35-42. https:/ / simdos.unud.ac.id/uploads/ file_penelitian_1_dir/6a074eb5c11df6 0b5fc5659b24ea45d0.pdf

Zou, T, -B., Xia, E, -Q., He, T, -P., Huang, M, -Y., Jia, -Q., Li, H, -W., 2014. Ultrasound assisted extraction of mangiferin from mango (Mangifera indica L.) leaves using response surface methodology. Molecules. 19, 1411-1421. https://doi. org/10.3390/molecules19021411 